\title{
Leaf-litter overyielding in a forest biodiversity experiment in subtropical China
}

\author{
Yuanyuan Huang ${ }^{1}$, Keping $\mathrm{Ma}^{2}$, Pascal A. Niklaus ${ }^{1}$ and Bernhard Schmid ${ }^{1,3^{*}}$ (D)
}

\begin{abstract}
Background: The production and subsequent turnover of aboveground litter is an important process in the ecosystem carbon (C) cycle. Litterfall links above- and belowground processes by transferring organic material to the soil where it becomes available to heterotrophs, fueling nutrient cycling. Little is known about how litter fluxes respond to experimental manipulation of tree species richness.

Methods: We sampled litterfall in a large-scale forest biodiversity experiment in subtropical China. Litter was collected at monthly intervals during peak senescing season for two years and throughout the whole year in 2016, using $0.75 \mathrm{~m} \times 0.75 \mathrm{~m}$ litter traps, in plots with a tree species richness of 1, 2, 4, 8 and 16 species.

Results: Cumulated annual litter production increased with tree species richness from an average of $1.96 \pm 0.25$

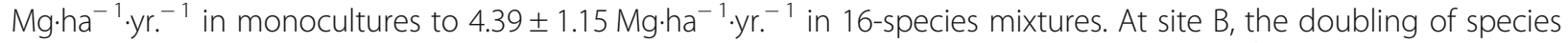
richness resulted in a positive effect with peak litter production increasing from $0.09 \mathrm{Mg}^{-\mathrm{ha}^{-1}}$ when trees were 5

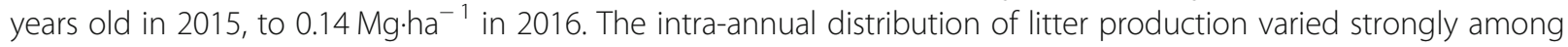
species, leading to a larger community niche for seasonal distribution of litter in species-rich than in species-poor plots. Community-niche size was positively correlated with litter production, thus providing an explanation for the species richness effects.

Conclusions: Different species had complementary temporal dynamics of litterfall, which led to a more or less constant litter supply in species-rich stands over the whole year. This caused positive richness effects on litter production which in turn may positively affect mineralization and subsequent tree growth.
\end{abstract}

Keywords: BEF-China, Temporal complementarity effects, Litterfall, Overyielding, Species richness

\section{Background}

Forests harbor one third of the terrestrial higher plant species (FAO 2015), with large contributions from subtropical and tropical regions. These forests provide important ecosystem services to humans such as the production of timber and fiber, production of energy, opportunities for recreation, and the regulation of local and global climate via carbon sequestration and transpiration. However, there is growing concern that species loss could impair these

\footnotetext{
* Correspondence: bernhard.schmid@uzh.ch

'Department of Evolutionary Biology and Environmental Studies, University

of Zürich, Winterthurerstrasse 190, 8057 Zürich, Switzerland

${ }^{3}$ Department of Geography, University of Zürich, Winterthurerstrasse 190,

8057 Zürich, Switzerland

Full list of author information is available at the end of the article
}

ecosystems and therefore also the services that they provide (Díaz et al. 2006; Pukkala 2016).

Researchers already dug deep into the relation between biodiversity and ecosystem functioning (BEF) in grassland (Tilman et al. 2014). However, BEF research in forest ecosystems is still at its beginning and experimental evidence about effects of tree species richness (Verheyen et al. 2016) and the underlying mechanisms is largely lacking, not least because of the large time spans required for forest experiments to be set up (Scherer-Lorenzen 2014), especially in tropical and subtropical areas (Gautam and Mandal 2016; Clarke et al. 2017). Current forest BEF research has shown that species richness indeed increases productivity and the stability of productivity (Liang et al. 2016; Huang et al. 2018), and these diversity effects can be 
caused by positive direct interactions of species (e.g. facilitation) (Wright et al. 2017) or niche-based differences between species. Current niche-based complementarity (Turnbull et al. 2016) explains that diverse communities can make better use of resources by taking up different resources, including nutrient, water, light, space etc. (Tilman et al. 1997; von Felten et al. 2009; Zeugin et al. 2010; Jucker et al. 2015; Niklaus et al. 2017; Van de Peer et al. 2017; Williams et al. 2017). However, long-term studies in forests focusing on complementarity are scarce (Sapijanskas et al. 2014).

Other research suggests that neutral processes may be important in species-rich forest because diffuse coevolution results in niche convergence toward generalist strategies (Hubbell 2006; Wang et al. 2016). If this would indeed be the case, one might expect some functional redundancy among species in highly diverse forests, and the loss of species would have no or only comparably little consequences for some elements of ecosystem functioning (Lawton and Brown, 1994).

One ecosystem function, litter production, links aboveground autotrophic production to belowground heterotrophic processes. However, litter production has consequences beyond carbon $(\mathrm{C})$ cycling. Physically, a tree litter layer enhances soil moisture and stabilizes soil temperature through insulation (Thompson 2011). Chemically, litter quantity and quality fuel heterotrophic processes and promote nutrient mineralization (Manzoni et al. 2008), thereby recycling nutrients that support future plant growth. Litter production and decomposition may thus present an important mechanism that contributes to the interaction of neighboring trees (Sapijanskas et al. 2013), giving rise to competitive and facilitative effects. For example, in a study of permanent forest plots across Germany (Pretzsch et al. 2010), Norway spruce (Picea abies) benefited from a continuous facilitation by European beech (Fagus sylvatica), but only on nutrient-poor soil. This effect most likely emerged from nutrient transfer from beech to spruce through litter decomposition. More generally, niche differentiation of nutrient uptake between species may be a mechanism that promotes stand-level tree growth.

However, there are only few studies analyzing the effect of tree species richness on litter production. Some studies have compared litter production in monoculture plantations with that in natural forests (Yang et al. 2004). Few diversity-related observational studies suggest that more diverse mixtures of tree species produce more litter (Pretzsch et al. 2010) and can change litter quality (Huang et al. 2017). Still, there are many factors in observational studies, such as stand age, tree density and topography, that can mask the effects of tree diversity, and it thus remains difficult to unequivocally attribute effects on litterfall to tree species richness (Mori 2017). Manipulative experiments allow control over environmental factors in such a way that they are similar for different biodiversity levels, and it allows for the identification of causal mechanisms behind an observation. Support for tree diversity effects on litterfall by data from manipulated forest biodiversity experiments, however, is limited and equivocal (Scherer-Lorenzen et al. 2007).

We investigated the relationship between tree species richness and litter production in a large-scale forest biodiversity experiment set up in subtropical China. We measured litterfall in plots with 1, 2, 4, 8 and 16 species. These measurements were made monthly during the growing season over two consecutive years from 2014 to 2015, and throughout the whole year in 2016. Specifically, we tested whether 1) stand- or community-level litter production increased with tree species richness, 2) this relationship strengthened through time and 3) species showed intra-annual complementarity in litterfall dynamics, which potentially explained higher litter production in mixed-species stands.

\section{Methods \\ Experimental design}

The present study was carried out as part of a large forest biodiversity experiment, "BEF-China", which was established near the village of Xingangshan in Jiangxi Province in south-east China $\left(29^{\circ} 08^{\prime}-29^{\circ} 11^{\prime} \mathrm{N}, 117^{\circ} 90^{\prime}-117^{\circ} 93^{\prime} \mathrm{E}\right)$. The climate at the site is subtropical, with a mean annual temperature of $17{ }^{\circ} \mathrm{C}$ and a mean annual precipitation of $1800 \mathrm{~mm}$ (averaged from 1971 to 2000) (Yang et al. 2013). During the study period 2014-2016, mean annual temperature was $18.0^{\circ} \mathrm{C}, 17.5^{\circ} \mathrm{C}$ and $18.0^{\circ} \mathrm{C}$, whereas annual precipitation was 2110,2632 and $1944 \mathrm{~mm}$, respectively (http://data.cma.cn). The experiment was set up at two sites (site A in 2009 and site B in 2010) that are $5 \mathrm{~km}$ apart, each covering an area of about 20 ha. There are a total of 566 plots, each with an area of $25.8 \mathrm{~m} \times 25.8 \mathrm{~m}$ in horizontal projection and planted with 400 trees arranged on a rectangular $20 \times 20$ grid with $1.29 \mathrm{~m}$ distance between neighbors, i.e. 6000 trees per hectare (Bruelheide et al. 2014). Here, we chose plots from one species pool in each site that spanned complete tree species richness gradients of 1, 2, 4, 8, 16 (Fig. 1). At each site, an independent set of 16 species (referred to as species pool) was repeatedly randomly divided into halves, halves of halves and so on until 16 monocultures per pool were obtained. This nested experimental design ensured that all species were equally represented at all diversity levels, i.e. that effects of species richness and of species identity were orthogonal. All community compositions obtained with this procedure were established in two plots positioned randomly within each site, with the restriction that they were at least $100 \mathrm{~m}$ apart. In total, there were 62 unique community compositions: two 16 -species mixtures, four 8 -species 


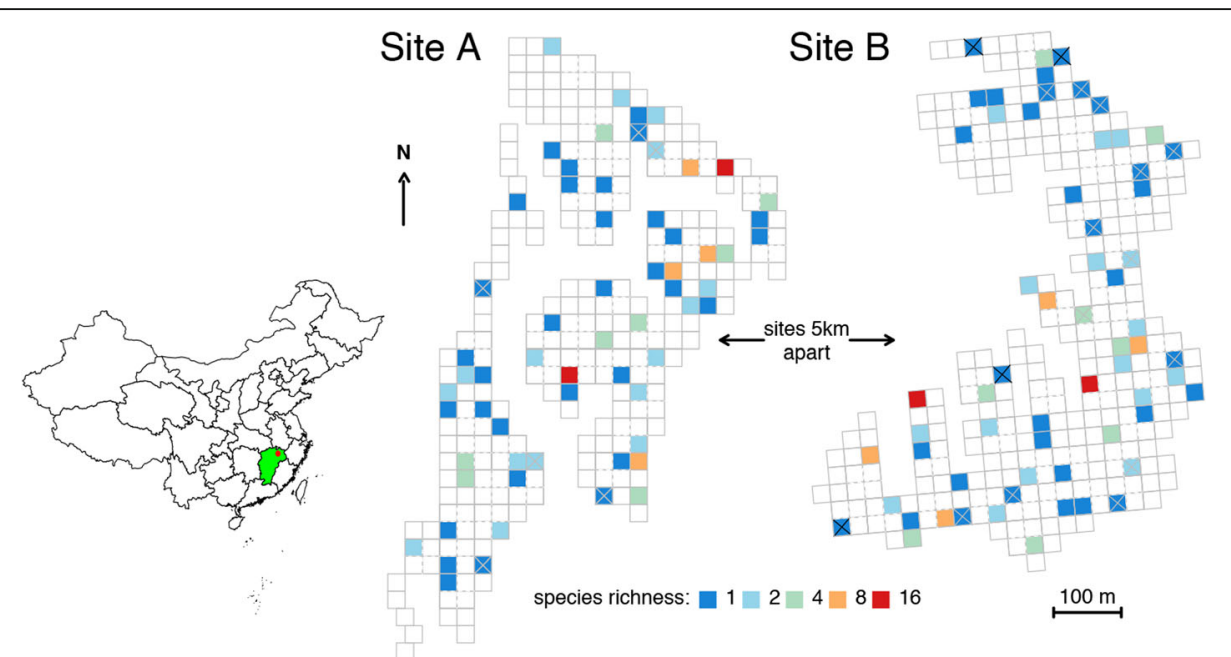

Fig. 1 Map of study area and experimental plots. Each square represents a plot. Left map shows the experimental site location -- Xingangshan (the red point) in Jiangxi Province (the green area). The right part shows information about the experimental plots

mixtures, eight 4-species mixtures, 16 two-species mixtures, and 32 monocultures. Both deciduous and evergreen species were included in these mixtures; see Fig. 3 for species planted in the chosen experimental plots.

We measured the basal diameter of all surviving trees among the 16 trees planted in the center of each plot at 5 $\mathrm{cm}$ height to calculate stand basal area (Huang et al. 2018). The mean tree basal area in year 2014, 2015, 2016 was 7.37 $\pm 0.61,9.59 \pm 0.73,12.48 \pm 0.92 \mathrm{~m}^{2} \cdot \mathrm{ha}^{-1}$, respectively.

\section{Litter collection}

We installed 3 litter traps in the central area of each plot in March 2014 at site A (trees were planted in 2009) and in March 2015 at site B (trees were planted in 2010). Litter traps were made of nylon nets $(1 \mathrm{~mm}$ mesh) placed over a PVC frame with a horizontal trapping area of 0.75 $\mathrm{m} \times 0.75 \mathrm{~m}$. The litter traps were placed under the tree canopy 1-1.5 $\mathrm{m}$ above ground level, depending on the size of the trees. Plots with a maximum tree height below $1 \mathrm{~m}$ were not equipped with traps because these would not have collected significant amounts of leaf litter (litterfall of which were accounted as 0 ). At sites A and B, 56 and 45 plots were fitted with traps, respectively. In site B, two Meliosma flexuosa monocultures, one Machilus grijsii plot and one Quercus phillyreoides plot could not be established in the beginning, so they were excluded from analysis. Thus, in total there were 120 plots on which we base our results (Fig. 1).

Litter collection started in September 2014 at site A and September 2015 at site B. In 2014 and 2015, litter was collected from September 1 to November 31, which is the main leaf shedding season. In 2016, litter was collected throughout the year. Litter traps were emptied once per month. In 2014 (the first year), we separated litter into leaf litter and non-leaf fractions (fine branches $\leq 2.5 \mathrm{~cm}$ in diameter, bark, reproductive structures, animal detritus, and other unidentified fine litter). However, only about $5 \%$ of the total was in the non-leaf fraction and we therefore stopped separating litter thereafter. Litter amounts were very low in February and June 2016, and we therefore collected the litter together with the one trapped in the following month. All litter samples were weighed after oven-drying at $60^{\circ} \mathrm{C}$ for $48 \mathrm{~h}$.

\section{Overyielding and transgressive overyielding}

To detect diversity effect on litterfall, we calculated litterfall overyielding in mixtures. Overyielding describes the case where the productivity of a mixture exceeds the average productivity of monocultures of component species (Schmid et al. 2008). Transgressive overyielding indicates that the productivity of a mixture exceeds the productivity of the monoculture of the most productive component species.

\section{Statistical analyses}

We analyzed the tree species richness effects on litter production and predicted values for regression displays with linear mixed-effects models using ASReml-R (Butler et al. 2007). Litterfall data were squared-root transformed to meet assumptions of variance homogeneity and normality. The analysis of variance was based on type-I sum of squares. When the data from multiple years were analyzed together, since litter was collected for different years, we analyzed the data from the two sites separately. The fixed-effects terms in the mixed-effects model were fitted in this sequence: $\log S R+$ year $+\log S R \times$ year, where $\log S R$ refers to log-2-transformed tree species richness. The random-effects terms used were species composition + species 
composition $\times$ year. Species composition and its interactions must be fitted as random-effects term in biodiversity experiments to obtain correct error terms for species richness effects and its interactions (Schmid et al. 2017).

When yearly litterfall data from 2016 were analyzed, the fixed effects were: site $+\operatorname{logSR}$, and the random effect was species composition.

To test whether interspecific intra-annual temporal complementarity of litterfall contributed to a higher production of litter in mixtures, we determined a community-niche metric (Salles et al. 2009):

$$
\text { Community Niche }=\sum_{t=1}^{12} \max _{\mathrm{sp}=1 \ldots \mathrm{S}}\left(P_{t, \mathrm{sp}}\right),
$$

where $P_{t, \mathrm{sp}}$ is the proportion of annual litter produced by species sp in month $t$ ( $P$ sums to unity for each species and a full year). We then fit community niche before or after log-species richness) in the mixed-effects models described above.

Pearson correlation analysis was used to get the correlation between plot litterfall and stand basal area. A Chi-squared test was performed to examine the significance of the difference between overyielding plot numbers and non-overyielding plot numbers. All analyses were done in $\mathrm{R}$ 3.3.2.

\section{Results}

In 2016, annual litter production averaged $3.00 \pm 0.28$

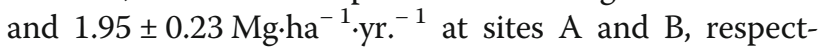
ively, with maximum plot values of 6.82 and $6.49 \mathrm{Mg}^{-h^{-}}$ ${ }^{1}$.yr. $^{-1}$. The intra-annual litterfall dynamics exhibited a bimodal shape with a small peak from April to May and a large peak from September to November. This pattern was particularly evident in species-rich communities (Fig. 2). Species differed in annual litter production and temporal litterfall dynamics (Fig. 3), with deciduous species peaking in fall (Fig. 3a and b; e.g. Nyssa sinensis, Liquidambar formosana, Alniphyllum fortunei, Choerospondias axillaris) and evergreen species peaking in spring (Fig. 3c and d; e.g. Schima superba).

Litter production in 2016 increased with tree species richness (Figs. 4 and 5a, $F_{1,57.4}=8.78, P=0.004$ ). Annual litterfall in the average 16 -species mixture $(4.39 \pm 1.15$

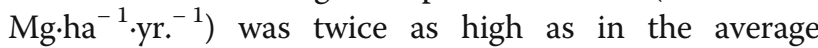

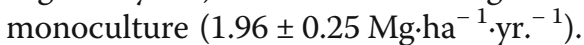

Peak season (September to November) litter production increased through time (Table $1, P \leq 0.001$ ) at both sites (A: 2014-2016; B: 2015-2016). Peak season litter production increased more quickly in more species-rich communities, resulting in biodiversity effects that increased in the course of the experiment (Fig. 4). This increase was non-significant at site A but statistically significant at site $\mathrm{B}(P=0.115$ and $P=0.013$ for $\operatorname{logSR} \times$ year at sites $A$ and $B$, respectively; Table 1$)$. At site $B$, the doubling of species richness resulted in a positive effect with peak litter production increasing from 0.09

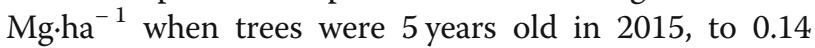

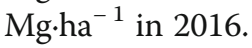

We determined overyielding of annual litter production in 2016, i.e. the extra litter produced in mixtures relative to the average of the component monocultures. In 2016, significantly more mixture plots overyielded than underyielded in both sites ( 23 vs. $\left.7, P\left(\chi^{2}{ }_{1}=7.5\right)=0.006\right)$. Out of 30 cases, there were 13 cases of transgressive overyielding,

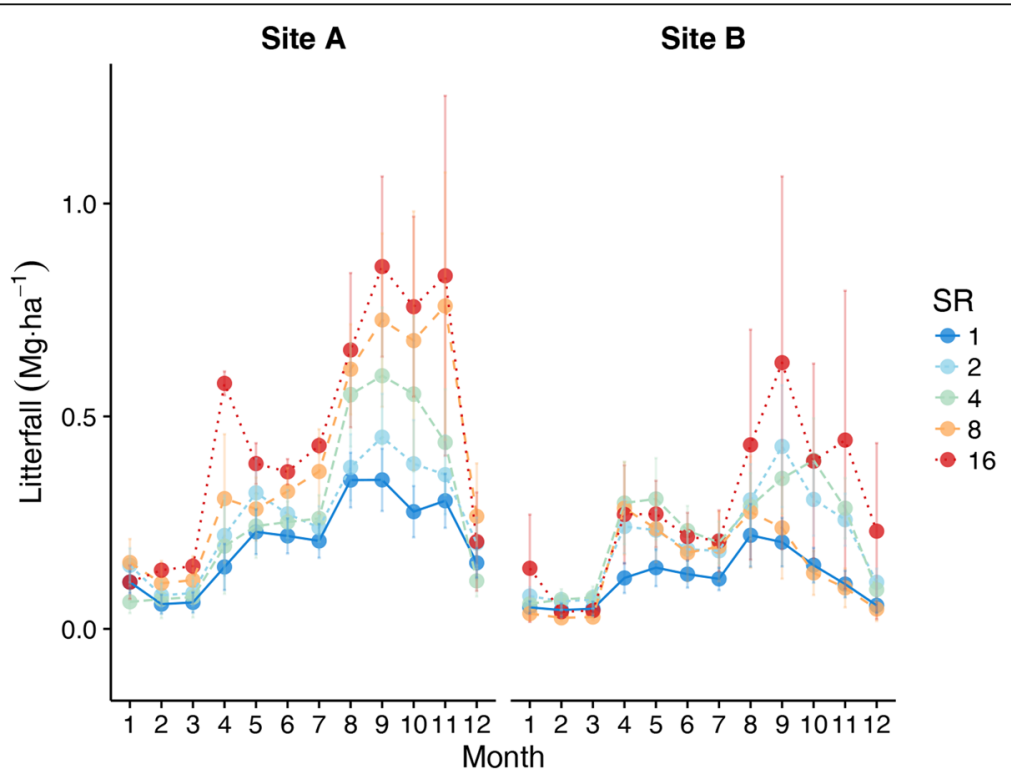

Fig. 2 Temporal dynamics of litterfall in experimental tree stands ranging in species richness (SR) from 1 to 16. Data are shown for the year 2016, separately for two field sites, each with its own pool of 16 tree species. Symbols indicate means \pm standard errors 

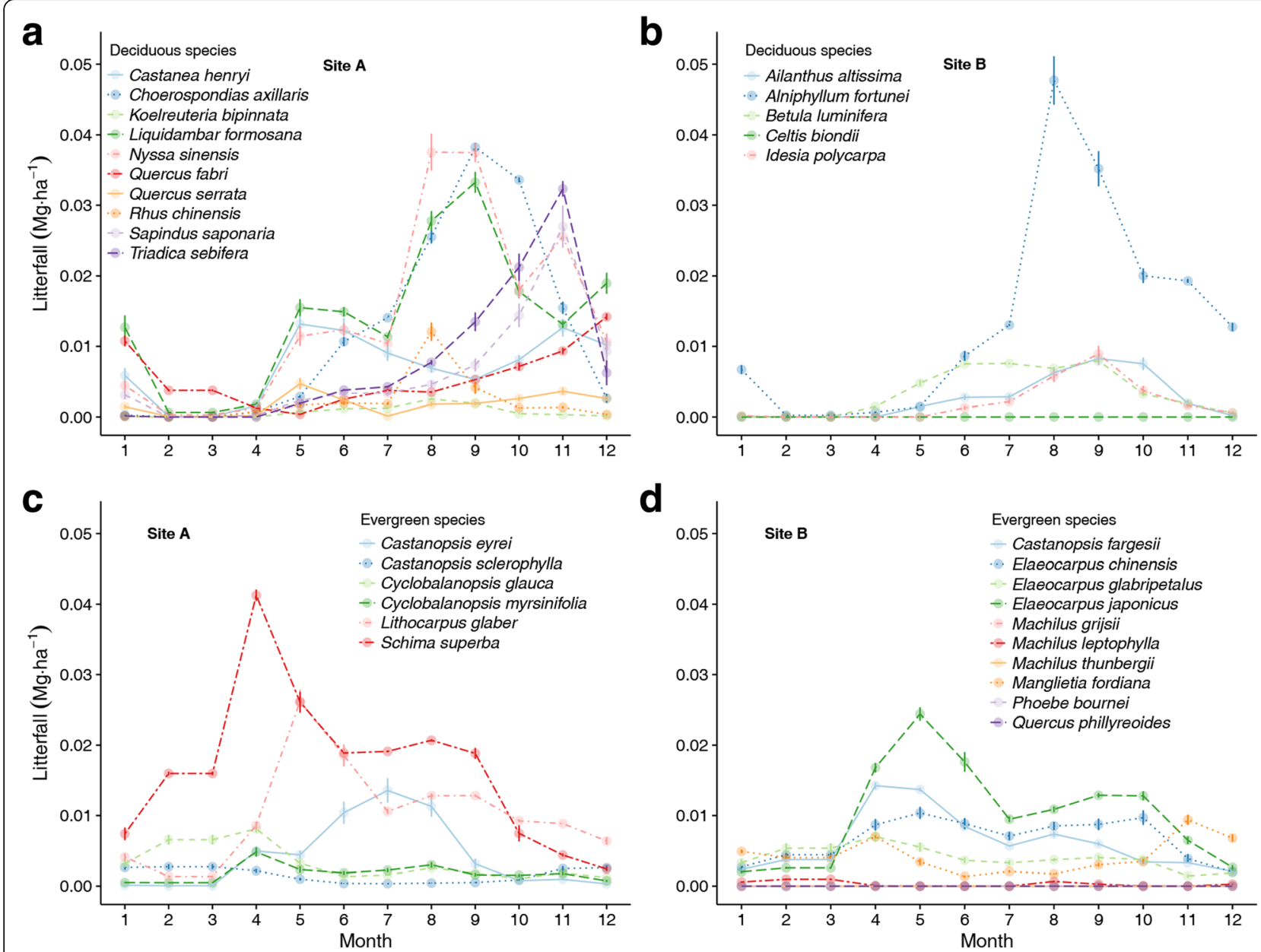

Fig. 3 Litterfall dynamics in monocultures. Data are shown for the year 2016, separately for site A (a, c) and site B (b, d) and for deciduous (a, b) and evergreen species $(\mathbf{c}, \mathbf{d})$. Symbols indicate means \pm standard errors

i.e. mixtures that outperformed their 'best' component monoculture (Schmid et al. 2008).

Species differed in intra-annual litterfall dynamics. As a consequence, more diverse species mixtures had a larger community niche value. The calculated community niche correlated positively with log-species richness (Pearson's product-moment correlation $r=0.91, n=59$, $P<0.001$, Fig. 5 b). While community niche explained community-level annual litter production slightly better than did species richness, it did not explain significant amounts of variation in addition to the variation explained by species richness (Table 2, Fig. 5).

\section{Discussion}

Seven years after the experiment had been planted, annual litter production of our tree communities at site A reached $3.0 \pm 0.3 \mathrm{Mg} \cdot \mathrm{ha}^{-1} \cdot \mathrm{yr}^{-1}$, which is similar to the litter production found in young stands in a nearby forest reserve (Huang et al. 2017). We found positive effects of tree species richness on annual leaf litter production, with most mixtures overyielding their average constituent monocultures, some even transgressively overyielding their best constituent monoculture. This result matches with our previous findings in nearby natural forest (Huang et al. 2017). These effects also parallel effects observed earlier for leaf area index in the same plots (Peng et al. 2017). There was also a strong positive correlation between litterfall and stand basal area at both sites (Pearson's product-moment correlation $r=0.83$, $n=60, P<0.001$ for site A; $r=0.76, n=56, P<0.001$ for site B). In general, litter production rates likely follow responses of aboveground productivity to biodiversity, which suggests that complementarity effects (caused by direct positive species interaction or niche-based differences among species) or selection effects (the contribution of a single or few dominant species to overyielding) caused the positive effects of tree species richness on annual and peak season litter production.

Our experimental tree communities had been planted only 4 to 7 years prior to the reported litterfall 

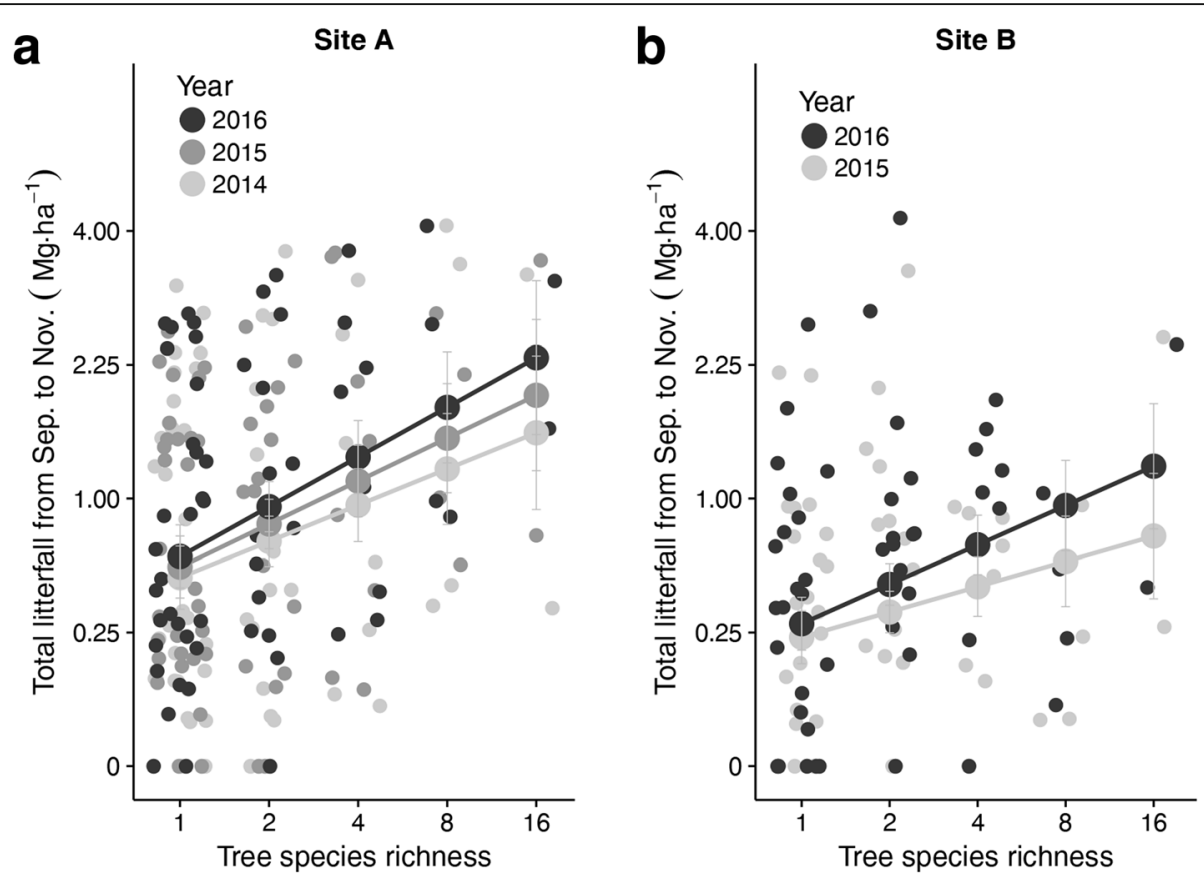

Fig. 4 Relationships between tree species richness and peak season litter production for different years at site A (a) and site B (b). Small dots represent the raw data, regression lines, large dots and standard errors are predictions from mixed-effects models. Note the square-root scale of the $y$ axis

measurements, and the diversity effects were continually increasing during this time (Fig. 4). However, the study from the nearby natural forest (Huang et al. 2017) found no further differences in diversity effect on litterfall between stand aged 22 years and older. The overyielding effects in our experiment may thus soon reach a constant value.

Interspecific differences in intra-annual litterfall dynamics corroborate findings from other studies (Scherer-Lorenzen et al. 2007), but in our study the positive effect of species richness was stronger. The Scherer-Lorenzen et al. (2007) study involved a much shorter richness gradient from one to six species and due to a non-random planting pattern within plots, maximum neighborhood diversity was only three species. In addition, the absence of diversity effects in that study might also have been due to a short litterfall collection period (February to April), which may have masked the advantage of larger community niches with regard to litterfall dynamics in more species-rich forests. In our study, species-rich forests had larger community niches, indicating a temporally more constant litterfall throughout the year in mixed communities due to complementary litterfall dynamics between species, in particular when deciduous and evergreen species grow together.

Soil erosion is a major disturbance in the experimental region (high rainfall intensities) (Seitz et al. 2015) and contributes to soil degradation with consequences for soil fertility and water storage. In a study conducted in open forest near our field site (Seitz et al. 2015) found that a litter layer can provide effective protection of the soil surface against erosion due to rain splash. Similarly (Li et al. 2014) reported delayed run-off and lower erosion rates when litter cover was enhanced in experimentally irrigated field plots in temperate oak and pine forest. The soil litter layer also mediates larger-scale hydrology by buffering water fluxes. The litter layer reduces run-off after precipitation, and this effect has been reported at the watershed-scale in a litter removal study (Gomyo and Kuraji, 2016). The soil litter layer can also reduce soil evaporation during dry periods ( $\mathrm{Li}$ et al. 2013). Overall, litter thus contributes to the buffering of water stores in ecosystems. We have not quantified erosion in our study, but the larger amounts of leaf litter shed in more diverse plots, combined with a temporally more even distribution of inputs, will likely have resulted in a higher average soil cover by litter. It therefore appears plausible that more efficient protection from erosion and possibly also reduced soil evaporation can be gained by planting or maintaining mixtures of tree species.

Leaf litter fluxes are important for nutrient re-cycling. In 2-3 year-old tree stands at our study site, decomposition rates of standardized leaf litter samples decreased marginally with species diversity, most likely due to micro-climatic effect of the more developed tree canopies at higher tree species richness (Seidelmann et al. 2016). It is unclear, however, whether such an effect also will occur after full canopy closure. On the other hand, more diverse litter mixtures often, but not always, were found to 


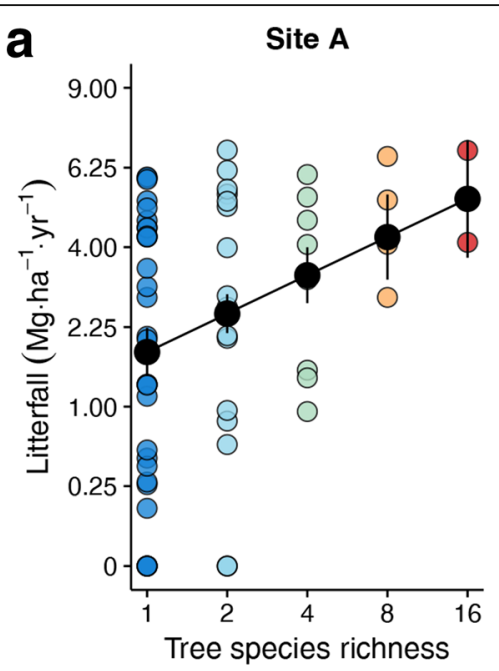

b

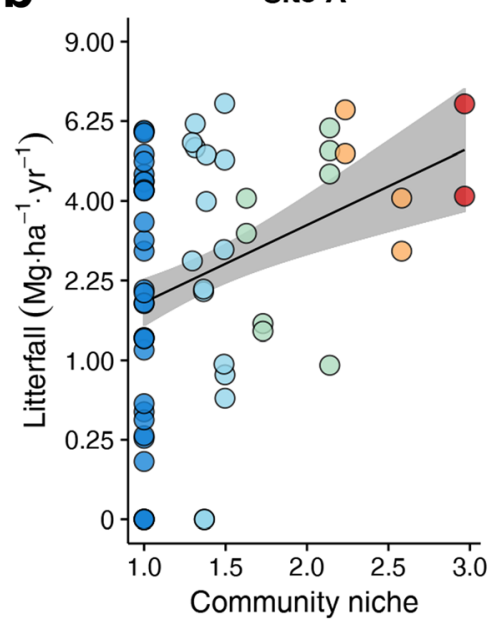

Site B
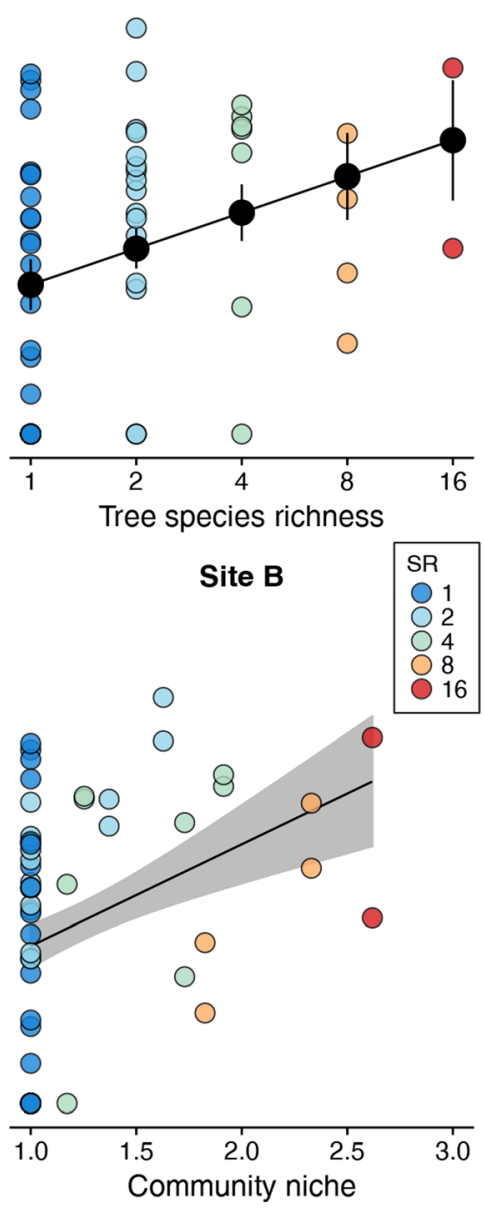

Fig. 5 Relationships between tree species richness (a) or community niche (b) and annual litter production in 2016. Colored dots represent the raw data with color indicating species richness; regression lines, black dots and standard errors are predictions from mixed-effects models. Note the square-root scale of the $y$ axis

Table 1 Analysis of variance (ANOVA) table testing for effects of tree species richness on peak season litterfall (September to November)

\begin{tabular}{lllll}
\hline Term & df & ddf & $F$ & $P$ \\
\hline Site A & & & & \\
logSR & 1 & 29 & 3.61 & 0.068 \\
year & 1 & 29 & 13.08 & 0.001 \\
logSR $\times$ year & 1 & 29 & 2.63 & 0.115 \\
Site B & & & & \\
logSR & 1 & 27.7 & 2.97 & 0.096 \\
year & 1 & 26.5 & 21.00 & $<0.001$ \\
logSR $\times$ year & 1 & 26.4 & 7.11 & 0.013
\end{tabular}

Note: fixed effects (log-transformed tree species richness, year, and the yeardependency of tree species richness) were fitted sequentially (type-I sum of squares) as indicated in the table. The data set for site $A$ includes 3 years (2014-2016), whereas the data set for site B includes 2 years (2015-2016). Year was fitted as continuous variable. $\mathrm{df}$ and $\mathrm{ddf}$ stand for numerator and denominator degree of freedom; $\log S R$ for $\log _{2}$ (tree species richness) and $F$ and $P$ for F-ratio and $P$-value of the significance tests
Table 2 Summary statistics from mixed-effects models for effects of community-niche size (Niche) and species richness (logSR) on annual litter production in 2016

\begin{tabular}{lllll}
\hline Terms & df & ddf & $F$ & $P$ \\
\hline Model 1 & & & & \\
Site & 1 & 56.6 & 5.67 & 0.021 \\
Niche & 1 & 56.1 & 9.32 & 0.003 \\
logSR & 1 & 56.6 & 0.12 & 0.730 \\
Model 2 & & & & \\
Site & 1 & 56.6 & 5.67 & 0.021 \\
logSR & 1 & 56.4 & 8.74 & 0.005 \\
Niche & 1 & 56.3 & 0.70 & 0.407 \\
\hline
\end{tabular}

Note: fixed effects were fitted sequentially (type-I sum of squares) as indicated in the table; $\mathrm{df}$ and ddf stand for numerator and denominator degree of freedom; $\log S R$ for $\log _{2}$ (tree species richness) and $F$ and $P$ for F-ratio and $P$-value of the significance tests 
decompose faster (Hättenschwiler et al. 2005). Fine roots play a critical role in the recycling of litter-borne nutrients, with particularly fast nutrient re-cycling when roots forage along the soil surface (Sayer et al. 2006). Such an effect may be stronger with a sufficient and temporally stable soil litter cover. However, we don't know whether this was important in our study. Overall, a multitude of processes are involved in controlling nutrient recycling rates, and it therefore remains difficult to speculate about the overall net effects of species diversity in our study without measuring these fluxes directly.

Litter fluxes can be important mediators of species interactions. In a study in mixed stands of Picea abies and Fagus sylvatica (Pretzsch et al. 2010) found that nutrients were effectively transferred from Fagus to Picea through the spreading and decomposition of mixed litter, which promoted the growth of Picea particularly on nutrientpoor soils and resulted in an overyielding of tree biomass in mixed species stands. Similar litterfall-mediated facilitation effects have been found in a range of studies (Wood et al. 2009; Sapijanskas et al. 2013). Overall, these studies, as well as the larger temporal community niche found in our study, strongly suggest that nutrient re-distribution among species may be an important driver of biodiversity-productivity effects in species-rich stands, through effects of complementarity. Testing such mechanism rigorously would, however, require the establishment of experimental litter removal or re-distribution treatments.

\section{Conclusion}

Our forest biodiversity experiment provides strong evidence that tree species richness can promote litter production and that this could be due to complementary litterfall dynamics between species in mixed stands. In our study, this complementarity resulted in more temporally stable litterfall rates in mixed stands, which may have additional implications for hydrology and rainfalldriven erosion.

\section{Acknowledgements}

We thank Chen Lin, Yang Bo and a large number of farmers for help with maintenance of the field experiment.

\section{Funding}

This study was funded by the EU 7th FP Project IDP-BRIDGES (Grant Number 608422 to B.S., K.M. and P.A.N.) and by the BEF-China Project, which is supported by the German Science Foundation (Grant FOR-891) and the Institute of Botany of the Chinese Academy of Sciences. B.S. and P.A.N. were additionally funded by the University of Zurich Research Priority Program on Global Change and Biodiversity (URPP GCB).

\section{Availability of data and materials}

The datasets used and analyzed during the current study are available from the corresponding author on reasonable request.

\section{Authors' contributions}

B.S., K.M. and P.A.N. designed the study. Y.H. set up the litter collection experiment and analyzed the data together with P.A.N. Y.H., P.A.N. and B.S. discussed the data and wrote the manuscript. All authors discussed, contributed and approved the final version.

Ethics approval and consent to participate

This research was performed in accordance with the laws, guidelines and ethical standards of China and Switzerland, where the research was performed.

\section{Competing interests}

The authors declare that they have no competing interests.

\section{Author details}

${ }^{1}$ Department of Evolutionary Biology and Environmental Studies, University of Zürich, Winterthurerstrasse 190, 8057 Zürich, Switzerland. ${ }^{2}$ State Key Laboratory of Vegetation and Environmental Change, Institute of Botany, Chinese Academy of Sciences, Beijing 100093, China. ${ }^{3}$ Department of Geography, University of Zürich, Winterthurerstrasse 190, 8057 Zürich, Switzerland

Received: 24 July 2018 Accepted: 5 November 2018

Published online: 22 November 2018

\section{References}

Bruelheide H, Nadrowski K, Assmann T, Bauhus J, Both S, Buscot F, Chen XY, Ding BY, Durka W, Erfmeier A, Gutknecht JLM, Guo DL, Guo LD, Hardtle W, He JS, Klein AM, Kuhn P, Liang Y, Liu XJ, Michalski S, Niklaus PA, Pei KQ, SchererLorenzen M, Scholten T, Schuldt A, Seidler G, Trogisch S, von Oheimb G, Welk E, Wirth C, Wubet T, Yang XF, Yu MJ, Zhang SR, Zhou HZ, Fischer M, Ma KP, Schmid B (2014) Designing forest biodiversity experiments: general considerations illustrated by a new large experiment in subtropical China. Methods Ecol Evol 5:74-89

Butler D, Cullis B, Gilmour A, Gogel B (2007) Analysis of mixed models for s language environments: Asreml - $\mathrm{R}$ reference manual. Queensland Department of Primary Industries and Fisheries, Brisbane

Clarke DA, York PH, Rasheed MA, Northfield TD (2017) Does biodiversity-ecosystem function literature neglect tropical ecosystems? Trends Ecol Evol 32:320-323

Díaz S, Fargione J, Chapin FS III, Tilman D (2006) Biodiversity loss threatens human well-being. PLoS Biol 4:e277

FAO (2015) Global forest resources assessment. Food and agriculture Organization of the United Nations, Rome

Gautam TP, Mandal TN (2016) Effect of disturbance on biomass, production and carbon dynamics in moist tropical forest of eastern Nepal. Forest Ecosyst. https://doi.org/10.1186/s40663-016-0070-y

Gomyo M, Kuraji K (2016) Effect of the litter layer on runoff and evapotranspiration using the paired watershed method. J For Res 21:306-313

Hättenschwiler S, Tiunov AV, Scheu S (2005) Biodiversity and litter decomposition in terrestrial ecosystems. Annu Rev Ecol Evol Syst 36:191-218

Huang Y, Chen Y, Castro-Izaguirre N, Baruffol M, Brezzi M, Lang A, Li Y, Härdtle W, von Oheimb G, Yang X, Liu X, Pei K, Both S, Yang B, Eichenberg D, Assmann $T$, Bauhus J, Behrens T, Buscot F, Chen X-Y, Chesters D, Ding B-Y, Durka W, Erfmeier A, Fang J, Fischer M, Guo L-D, Guo D, Gutknecht JLM, He J-S, He CL, Hector A, Hönig L, Hu R-Y, Klein A-M, Kühn P, Liang Y, Li S, Michalski S, Scherer-Lorenzen M, Schmidt K, Scholten T, Schuldt A, Shi X, Tan M-Z, Tang Z, Trogisch S, Wang Z, Welk E, Wirth C, Wubet T, Xiang W, Yu M, Yu X-D, Zhang J, Zhang S, Zhang N, Zhou H-Z, Zhu C-D, Zhu L, Bruelheide H, Ma K, Niklaus PA, Schmid B (2018) Impacts of species richness on productivity in a large-scale subtropical forest experiment. Science 362:80-83.

Huang Y, Ma Y, Zhao K, Niklaus PA, Schmid B, He J-S (2017) Positive effects of tree species diversity on litterfall quantity and quality along a secondary successional chronosequence in a subtropical forest. J Plant Ecol 10:28-35

Hubbell SP (2006) Neutral theory and the evolution of ecological equivalence. Ecology 87:1387-1398

Jucker T, Bouriaud O, Coomes DA (2015) Crown plasticity enables trees to optimize canopy packing in mixed-species forests. Funct Ecol 29:1078-1086

Lawton JH, Brown VK (1994) Redundancy in ecosystems. In: Schulze E-D, Mooney HA (eds) Biodiversity and ecosystem function. Springer Berlin Heidelberg, Berlin, Heidelberg, pp 255-270

Li X, Niu J, Xie B (2013) Study on hydrological functions of litter layers in North China. PLoS One 8:e70328

Li X, Niu J, Xie B (2014) The effect of leaf litter cover on surface runoff and soil erosion in northern China. PLoS One 9:e107789 
Liang J, Crowther TW, Picard N, Wiser S, Zhou M, Alberti G, Schulze E-D, McGuire $A D$, Bozzato $F$, Pretzsch $H$, de-Miguel $S$, Paquette A, Hérault $B$, SchererLorenzen M, Barrett CB, Glick HB, Hengeveld GM, Nabuurs G-J, Pfautsch S, Viana H, Vibrans AC, Ammer C, Schall P, Verbyla D, Tchebakova N, Fischer M, Watson JV, Chen HYH, Lei X, Schelhaas M-J, Lu H, Gianelle D, Parfenova El, Salas C, Lee E, Lee B, Kim HS, Bruelheide H, Coomes DA, Piotto D, Sunderland T, Schmid B, Gourlet-Fleury S, Sonké B, Tavani R, Zhu J, Brandl S, Vayreda J, Kitahara F, Searle EB, Neldner VJ, Ngugi MR, Baraloto C, Frizzera L, Bałazy R, Oleksyn J, Zawiła-Niedźwiecki T, Bouriaud O, Bussotti F, Finér L, Jaroszewicz B, Jucker T, Valladares F, Jagodzinski AM, Peri PL, Gonmadje C, Marthy W, O'Brien T, Martin EH, Marshall AR, Rovero F, Bitariho R, Niklaus PA, Alvarez-Loayza P, Chamuya N, Valencia R, Mortier F, Wortel V, Engone-Obiang NL, Ferreira LV, Odeke DE, Vasquez RM, Lewis SL, Reich PB (2016) Positive biodiversity-productivity relationship predominant in global forests. Science. https://doi.org/10.1126/science.aaf8957

Manzoni S, Jackson RB, Trofymow JA, Porporato A (2008) The global stoichiometry of litter nitrogen mineralization. Science. https://doi.org/10.1126/science.1159792

Mori AS (2017) Environmental controls on the causes and functional consequences of tree species diversity. J Ecol 106:113-125

Niklaus PA, Baruffol M, He J-S, Ma K, Schmid B (2017) Can niche plasticity promote biodiversity-productivity relationships through increased complementarity? Ecology 98:1104-1116

Peng S, Schmid B, Haase J, Niklaus PA (2017) Leaf area increases with species richness in young experimental stands of subtropical trees. J Plant Ecol 10:128-135

Pretzsch H, Block J, Dieler J, Dong PH, Kohnle U, Nagel J, Spellmann H, Zingg A (2010) Comparison between the productivity of pure and mixed stands of Norway spruce and european beech along an ecological gradient. Ann For Sci 67:712-712

Pukkala T (2016) Which type of forest management provides most ecosystem services? Forest Ecosyst. https://doi.org/10.1186/s40663-016-0068-5

Salles JF, Poly F, Schmid B, Roux Xavier L (2009) Community niche predicts the functioning of denitrifying bacterial assemblages. Ecology 90:3324-3332

Sapijanskas J, Paquette A, Potvin C, Kunert N, Loreau M (2014) Tropical tree diversity enhances light capture through crown plasticity and spatial and temporal niche differences. Ecology 95:2479-2492

Sapijanskas J, Potvin C, Loreau M (2013) Beyond shading: litter production by neighbors contributes to overyielding in tropical trees. Ecology 94:941-952

Sayer EJ, Tanner EVJ, Cheesman AW (2006) Increased litterfall changes fine root distribution in a moist tropical forest. Plant Soil 281:5-13

Scherer-Lorenzen M (2014) The functional role of biodiversity in the context of global change. In: Coomes DA, Burslem DFRP, Simonson WD (eds) Forests and global change. Cambridge University Press, Cambridge, pp 195-238

Scherer-Lorenzen M, Luis Bonilla J, Potvin C (2007) Tree species richness affects litter production and decomposition rates in a tropical biodiversity experiment. Oikos 116:2108-2124

Schmid B, Baruffol M, Wang Z, Niklaus PA (2017) A guide to analyzing biodiversity experiments. J Plant Ecol 10:91-110

Schmid B, Hector A, Saha P, Loreau M (2008) Biodiversity effects and transgressive overyielding. J Plant Ecol 1:95-102

Seidelmann KN, Scherer-Lorenzen M, Niklaus PA (2016) Direct vs. microclimatedriven effects of tree species diversity on litter decomposition in young subtropical forest stands. PLoS One 11:e0160569

Seitz S, Goebes P, Zumstein P, Assmann T, Kühn P, Niklaus PA, Schuldt A Scholten T (2015) The influence of leaf litter diversity and soil fauna on initial soil erosion in subtropical forests. Earth Surf Proc Land 40:1439-1447

Thompson K (2011) Life after death: the role of litter in ecosystems. Funct Ecol 26:262-265

Tilman D, Isbell F, Cowles JM (2014) Biodiversity and ecosystem functioning. Annu Rev Ecol Evol Syst 45:471-493

Tilman D, Lehman CL, Thomson KT (1997) Plant diversity and ecosystem productivity: theoretical considerations. P Natl Acad Sci 94:1857-186

Turnbull LA, Isbell F, Purves DW, Loreau M, Hector A (2016) Understanding the value of plant diversity for ecosystem functioning through niche theory. $\mathrm{P}$ Roy Soc B: Biol Sci. https://doi.org/10.1098/rspb.2016.0536

Van de Peer T, Verheyen K, Ponette Q, Setiawan NN, Muys B (2017) Overyielding in young tree plantations is driven by local complementarity and selection effects related to shade tolerance. J Ecol. https://doi.org/10.1111/1365-2745.12839

Verheyen K, Vanhellemont M, Auge H, Baeten L, Baraloto C, Barsoum N, BilodeauGauthier S, Bruelheide H, Castagneyrol B, Godbold D, Haase J, Hector A, Jactel H, Koricheva J, Loreau M, Mereu S, Messier C, Muys B, Nolet P, Paquette A, Parker J, Perring M, Ponette Q, Potvin C, Reich P, Smith A, Weih
M, Scherer-Lorenzen M (2016) Contributions of a global network of tree diversity experiments to sustainable forest plantations. Ambio 45:29-41

von Felten S, Hector A, Buchmann N, Niklaus PA, Schmid B, Scherer-Lorenzen M (2009) Belowground nitrogen partitioning in experimental grassland plant communities of varying species richness. Ecology 90:1389-1399

Wang X, Wiegand T, Kraft NJB, Swenson NG, Davies SJ, Hao Z, Howe R, Lin Y, Ma K, Mi X, Su S-H, Sun IF, Wolf A (2016) Stochastic dilution effects weaken deterministic effects of niche-based processes in species rich forests. Ecology 97:347-360

Williams LJ, Paquette A, Cavender-Bares J, Messier C, Reich PB (2017) Spatial complementarity in tree crowns explains overyielding in species mixtures. Nat Ecol Evol 1:0063

Wood TE, Lawrence D, Clark DA, Chazdon RL (2009) Rain forest nutrient cycling and productivity in response to large-scale litter manipulation. Ecology 90:109-121

Wright AJ, Wardle DA, Callaway R, Gaxiola A (2017) The overlooked role of facilitation in biodiversity experiments. Trends Ecol Evol 32:383-390

Yang X, Bauhus J, Both S, Fang T, Härdtle W, Kröber W, Ma K, Nadrowski K, Pei K, Scherer-Lorenzen M, Scholten T, Seidler G, Schmid B, Oheimb G, Bruelheide H (2013) Establishment success in a forest biodiversity and ecosystem functioning experiment in subtropical China (BEF-China). Eur J For Res 132:593-606

Yang YS, Guo JF, Chen GS, Xie JS, Cai LP, Lin P (2004) Litterfall, nutrient return, and leaf-litter decomposition in four plantations compared with a natural forest in subtropical China. Ann For Sci 61:465-476

Zeugin F, Potvin C, Jansa J, Scherer-Lorenzen M (2010) Is tree diversity an important driver for phosphorus and nitrogen acquisition of a young tropical plantation? For Ecol Manag 260:1424-1433

\section{Submit your manuscript to a SpringerOpen ${ }^{\circ}$ journal and benefit from:}

- Convenient online submission

- Rigorous peer review

- Open access: articles freely available online

High visibility within the field

- Retaining the copyright to your article

Submit your next manuscript at $>$ springeropen.com 